\title{
WestVirginiaUniversity
}

THE RESEARCH REPOSITORY @ WVU

Graduate Theses, Dissertations, and Problem Reports

2009

\section{Community social status effects on migration outcomes}

Mark Gerald Middleton

West Virginia University

Follow this and additional works at: https://researchrepository.wvu.edu/etd

\section{Recommended Citation}

Middleton, Mark Gerald, "Community social status effects on migration outcomes" (2009). Graduate Theses, Dissertations, and Problem Reports. 760.

https://researchrepository.wvu.edu/etd/760

This Thesis is protected by copyright and/or related rights. It has been brought to you by the The Research Repository @ WVU with permission from the rights-holder(s). You are free to use this Thesis in any way that is permitted by the copyright and related rights legislation that applies to your use. For other uses you must obtain permission from the rights-holder(s) directly, unless additional rights are indicated by a Creative Commons license in the record and/ or on the work itself. This Thesis has been accepted for inclusion in WVU Graduate Theses, Dissertations, and Problem Reports collection by an authorized administrator of The Research Repository @ WVU. For more information, please contact researchrepository@mail.wvu.edu. 
Community Social Status Effects on Migration Outcomes

Mark Gerald Middleton

\begin{abstract}
Thesis submitted to the Eberly College of Arts and Sciences

at West Virginia University

In partial fulfillment of the requirements

For the degree of
\end{abstract}

\author{
Master of Arts \\ In \\ Applied Sociology
}

James J. Nolan, Ph.D., Chair

Ronald Althouse, Ph.D.

Jennifer Steele, Ph.D.

Division of Sociology and Anthropology

Morgantown, West Virginia

2009

Keywords: Migration, Residential Mobility 


\section{ABSTRACT \\ Community Social Status Effects on Migration Outcomes}

\section{Mark Gerald Middleton}

Using the geocoded version of the National Longitudinal Survey of Youth 1979

(NLSY79), this study examines patterns of internal migration in the United States by investigating individual residential mobility between low socioeconomic and high socioeconomic counties. Specifically, through the use of data between the years of 1979 and 2002, this study asks three questions. First, if the sending community is socioeconomically different than the receiving community where the migrant lives during middle age, does this show upward, downward or lateral status movement? Second, do migrants tend to move from less desirable communities to communities with higher socioeconomic standards of living? Third, what is the relationship between education and upward mobility, as the individual education levels increases is there movement to communities with higher socioeconomic standards of living? This analysis examines migration outcomes for individuals who in 1979 were between the ages of 14 and 21 and 23 years later where between the ages of 37 and 45 years of age in 2002, the latter period represents when individuals are entering middle age. Life cycle events, such as education, entry into the labor force and the start of marriage and childbearing tend to be complete at this stage of life cycle and migration is less frequent. 


\section{Table of Contents}

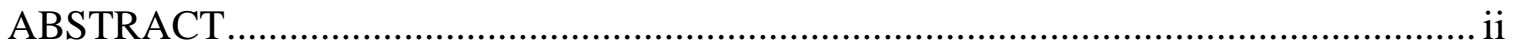

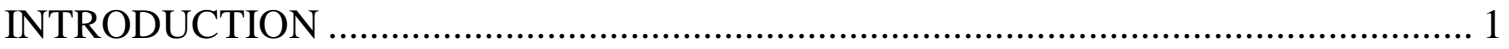

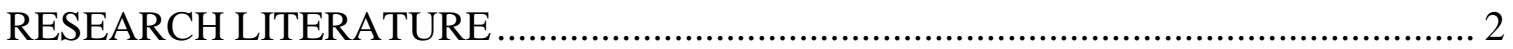

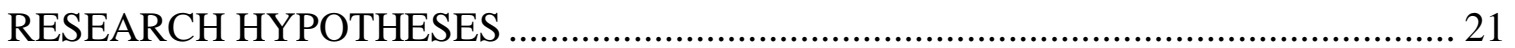

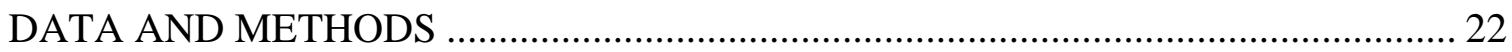

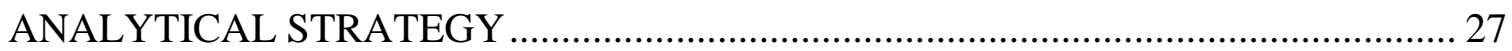

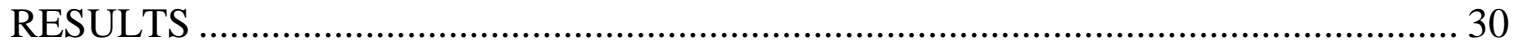

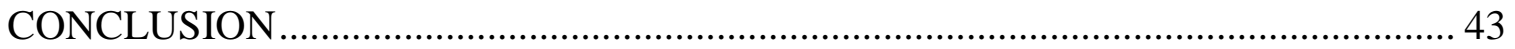

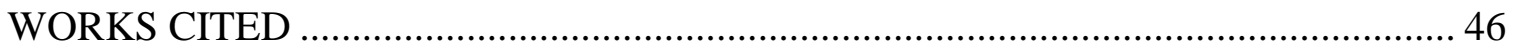




\section{INTRODUCTION}

Migration can be considered a social mechanism for the movement of human resources resulting in redistribution of a population to areas that need occupational skills in service (Blau and Duncan 1967). Opportunities vary between communities because of wealth, poverty, and social class associated with a geographic location (Blau and Duncan 1967; Logan and Molotch 1987). The community into which a person is born and lives ascribes status to the individual, and that status affects the individual's quality of life and life chances. The quality of education a person receives, access to healthcare, exposure to crime, entrée to employment opportunities and social prestige are all associated with the place one lives (Duncan 1992; Massey and Denton 1985; Tickamyer and Duncan 1990; Wilson 1996). Communities with higher social status tend to have better schools, higher quality health care and lower crime rates, while the opposite is true of communities with low socioeconomic status (Blau and Duncan 1967; Logan and Molotch 1987). The ascribed status of a community is not inescapable like race and ethnicity, because migration offers a way to escape a community and improve one's quality of life. As a channel for social and economic mobility, internal migration can offer opportunities to improve one's quality of life through movement to a new location (Blau and Duncan 1967). This allows the migrant to leave behind social and economic conditions in one community for opportunities in a new location. Moving from an area with limited economic prospects to a place with better opportunities is one way to improve access to employment opportunities and social mobility (Massey 1996). 
If internal migration between communities is for economic opportunities and improved social status then it can be logical to assume that those who migrate would move to receiving communities that offer greater economic opportunities in the form of higher incomes and lower unemployment rates with fewer people living in poverty than the sending communities they leave behind. This research examines long term outcomes of migration. As its focus the study exams middle age movers living in communities that are socioeconomically different than those they lived in at 14 years of age. This study only exams those that moved and were no longer living in the same county as they lived at age 14 and does not examine those who lived in the same county at age 14 and 2002.

Three questions are asked by the study:

1.) If the sending community is socio-economically different than the receiving community where the migrant lives during middle age, does this show upward, downward or lateral status movement?

2.) Do migrants tend to move from less desirable communities to communities with higher socioeconomic standards of living?

3.) What is the relationship between education and upward mobility, as the individual education levels increases is there movement to communities with higher socioeconomic standards of living?

\section{RESEARCH LITERATURE}

Most internal migration is the result of individuals moving to a location they think is better and offers more opportunities. The decision to migrate may be influenced by a change in housing, employment, or the preference for a set of local amenities that satisfies individual or family needs. Housing issues which can involve housing stock, 
neighborhood preferences or other local personal preferences are the most cited reasons for intra-county or local moves in the United States (U.S. Census Bureau 2004). Distance migrations that entail inter-county moves are also closely related to housing preferences, but these moves are also associated with economic opportunity moves (U.S. Census Bureau 2004). These economic moves can be triggered by new employment, job transfer or other opportunities that improve the economic positions of the migrant (U.S. Census Bureau 2005).

Internal migration research has historically been concerned with the demographics of migration and how demographic variables affect the decision to migrate. To view migration as a purely demographic phenomenon presents only a partial and incomplete view of migration. The social-psychological aspects of migration must also be observed in order to have a more complete understanding of internal migration. People do not just follow economic or political trends nor do they follow other migrants in a mindless fashion in their location to a new area. The impetus to relocate is made through a deliberate decision based on careful rational risk calculations of the costs and benefits of migration that also include emotions, wishes, fears and fantasias (Lee 1966). Social problems, such as employment opportunities, racial and ethnic segregation, occupational mobility, and community patterns of migration, are influential in migration decision

(Logan, et. al. 1996; South and Crowder 1997; Sjaatad 1962; Tadaro 1969; Wilson 1996; Wright, Ellis and Parks 2005).

\section{Demographic Patterns: Internal Migration}

Most migration research in the United States is concerned with the redistribution of population within the micro and macro data-determined frameworks. The micro 
approach to migration research tries to explain the psychology of the migration decision making process. The macro approach measures the characteristics of human variables, as well as socio economic and physical environments. The macro approach to migration considers the volume, direction and demographic characteristics of the migrant (Cadwallader 1992). Social researchers have examined how the decision to migrate is made, as well as the variables that interact to help determine the decision. Migration is a major component of population size, composition and rate of growth. Much of the research on migration investigates the demographic characteristics and their influence on the decision to move. Age, marriage, education and other human capital variables can be used to describe the general characteristics of those involved in population movement. The demographic characteristics of the migrating population cannot predict if an individual will migrate or explain why an individual migrated. Yet the demographics of migration are important to any study of migration since they describe the characteristics of those who migrate and are the foundation of migration theory.

\section{Age}

In general, age is one of the most consistent predictors in migration research (DaVanzo 1983; Goetz 1999). A younger individual is more likely to migrate than a middle aged or older person. As individuals age they are less likely to move except during the years around retirement (Cadwallader 1992; Haurin and Haurin 1988). Those under age 18 or people over 65 years of age are the least mobile (Greenwood 1975). People between the ages of 18 and 29 have the highest rate of migration (Cadwallader 1992). They are likely to be seeking new experiences (Seyfrith 1986). Youth are more mobile because three life cycle events tend to occur during this time in life. First, younger 
people move when they reach an age of emancipation, when they are unburdened by familial and work obligations. At this period in life youth tend to move from their parental home or "leave the nest" as they enter into adulthood. Second, after high school youth move to attend college or to seek employment (Greenwood 1975; Seyfrit 1986). Third, younger adults also move because they may plan to marry and begin families (Coté 1997; Greenwood 1975; Seyfrit 1986). After age 30 there is a large drop in the migration rate. Individuals are also less likely to move as they enter into the mid career of the life cycle (Haurin and Haurin 1988). This age group is more likely to be on track with an occupational career, married and raising a family (Blau and Duncan 1967). However, migration does increase for a short period of time at retirement age when there is a major change in life, and the retiree is free from their responsibilities of work and raising a family (Cadwallader 1992).

\section{Marriage}

Single individuals are more likely to migrate than married individuals; however, marriage is a life cycle event that often leads to migration. Single women are less likely to live in parental households or with close relatives than a single male, yet single women are less likely to migrate to a new community than single men, especially at younger ages (Mincer 1978). Men are more likely to migrate longer distances than women (Baryla and Dotterweich 2001; Mincer 1978; Wenk and Hardesty 1993), and single men migrate more than married men (Mincer 1978).

Couples tend to migrate at the start of a marriage. Young couples that are recently married have the highest rate of migration (Mincer 1978). As a family develops, it tends to change patterns. Interstate migration of married couples is highest for families who are 
younger, have school aged children, and are better educated and engaged in prestigious occupations (Lee and Roseman 1999). Migration diminishes for families with preschool age children present in the household (Lee and Roseman 1999). Families that have members who are poorly educated with lower occupational skills for employment also have diminished propensity to migrate (Lee and Roseman 1999). Age is also a factor that affects family migration. As the husband's and wife's age increases, family migration decreases (Spitze 1984).

With the exception of young couples, migration is lower for families in which the wife is employed (Mincer 1978). Historically; the wife's employment was less of an obstacle to family migration when the husband found employment in a different location because employment opportunities for the husband were the main concern for the family. Today, a woman's income is a factor in a family's economic interests, and her income is also a factor that can affect a family's migration decisions (Bielby and Bielby 1992; Spitze 1984). Family ties to an area tend to lengthen the period of unemployment in a location before the decision to migrate is made (Mincer 1978). The rate of married women in the labor force who moved is lower for women who are not working (Mincer 1978). When a married woman's permanent earning power is higher, it acts as a deterrent to migration. Yet, if the wife's earning power is low, it does not impact the migration decision (Mincer 1978).

\section{Race and Ethnicity}

Racial and ethnic groups tend to migrate for similar reasons are connected with class identity within a racial or ethnic group (Baryla and Dotterweich 2001; Spitz 1984). The tendency to migrate for racial or ethnic groups is most often related to age and 
education rather than racial or ethnicity (Gurak and Kritz 2000). Some researchers have found that African American men and women are less mobile than their white counterparts and that white college graduates migrate at a higher rate than nonwhite college graduates (Frey and Liaw 2005). However, black college graduates are more mobile than non-college graduates (Greenwood and Gormely 1971; Spitz 1984). Other researchers have found that Asian and Latino out-migration is lower than out-migrations for African Americans and whites (Frey and Liaw 2005).

There are several reasons for these racial/ethnic differences in patterns of migration. First, African Americans are not as likely to be informed of economic opportunities in other areas (Lee and Roseman 1999). Second, African Americana are less likely than whites to be in an occupation that offers opportunities for job transfer or to respond to specific job offers (Lee and Roseman 1999). African Americans are most likely to migrate to areas where unemployment is low and job opportunities are high (Greenwood and Glormely 1971). Latinos from areas with high unemployment rates tend to migrate more than Latinos (Baryla and Dotterweich 2001). On average, non whites are concentrated in positions of lower occupational status where job transfers are rare and unemployment is more common, while whites are more likely to be in the primary labor market with upward geographic mobility from job transfer (Greenwood 1975). In fact,

nonwhites who migrate are less likely than whites to have a job in hand when they move (Lee and Roseman 1999).

\section{Educational Attainment}

An individual's educational attainment and income can also influence a migration decision. Low educational attainment is an impediment to migration (Baryla and 
Dotterweich 2001). When those who are less educated migrate, they are less likely to have a job with the move (Greenwood 1975). Those with more skills are more likely to have a job when they move, either by taking a new job or because of a job transfer (Greenwood 1975). Migrants with a college degree or higher skill levels migrate longer distances than those with less skills (Cadwallader 1992; Greenwood 1975; Kodrzycki 2001). Those with higher skill levels often migrate at the end of a period of investment in human capital (Braswell and Gottesman 2001; Kodrizycki 2001). Completion of high school, a training program or college often precedes a move to a new location in order to redeem the investment in human capital (Greenwood 1975b). Those who have completed an education program have a newly acquired source of human capital; they are eager to trade the newly acquired capital for a return on their investment. Younger people who have recently completed high school tend to move for education and work; thus schooling and work can serve as migration pulls for younger people more than for older people. However, characteristics of place also matter. High school seniors in fast growing areas are less likely to move than seniors in slow growth areas (Greenwood 1975; Huang, Prazwm and Wohlgemuth 2002).

Individuals without a college degree who migrate move shorter distances after graduation than those with a college degree who are likely to move longer distances for employment after completion of a degree (Cadwallader 1992; Greenwood 1975b; Heuer 2004; Kodrzycki 2001). The correlation between education and distance of a move becomes stronger as the distance of a move increases (Greenwood 1975b). This has been attributed to the fact that the better educated individual competes in a national market 
providing those with a college degree the ability to market their skills nationally (Cadwallader 1992; Greenwood 1975b; Heuer 2004; Kodrzycki 2001).

That high school graduates in fast growing areas are not as likely to migrate illustrates that place matters. Improved job prospects, as measured by employment growth and unemployment, are more likely to be a migration draw for high school graduates than for college graduates (Haung, Prazwm, and Wholgemuth 2002). New employment opportunities in an area tend to decrease out migration (Huang, Prazwm and Wohlgemuth 2002). States with higher average pay are more likely to draw college graduates (Kodrzycki 2001). A college graduate's choice of migration locations is based more on work characteristics than on purely economic factors like salary and benefits (Braswell and Gottesman 2001).

The majority of college students attend college in the state where they attended high school (Kodrzycki 2001). It is also true that the majority of those with college degrees in a state went to high school in that state, although this does not mean that they return to the high school community (Kodrzycki 2001). While a majority of college students attend college in the state where they receive their high school education, one fifth of college freshmen migrate out of state to attend four year colleges (Heuer 2004). There is a high rate of non return for those students who migrate to attend college after completion of the degree (Baswell and Gottesman 2001; Kodrzycki 2001).

Education and training programs are two ways in which states invest in citizens, with the expectation that there will be a return on the investment at a future time (Haurin and Haurin 1988). For the state, this investment in education yields dividends, since most youth who complete high school and/or graduate from college in a state remain in the 
state for a least five years after graduation (Kodrzycki 2001). Still a significant portion of the state's population migrates, diminishing the potential return on the investment to the state (Frey 2004; Greenwood and Glormely 1971; Heuer 2004; Kodrzycki 2001).

\section{Theories of Migration}

Most of the current ideas on migration are based on the early work of E. G. Ravistein who published what he called Laws of Migration. These laws or generalization of migration state that for a majority of migrants, economics is the major factor for migration; the number of persons migrating decreases as distance increases; migration is rarely accomplished in one move but rather through a series of moves; the risk of migration is not the same for all persons but varies by demographic and social characteristics; and migration streams tend to create counter streams of return migrants (Ravenstein 1885, 1889). These simple axioms have a body of empirical research from throughout the world which has confirmed many of Ravenstein's hypotheses.

Ravenstein's laws were modified and extended by Everett S. Lee (1966) to include conditions that influence migration at the place of origin and destination, intervening obstacles and personal factors that influence migration. Under his theory, push and pull factors at both the migrant's point of origin and destination affect the decision to migrate. Negatively viewed variables tend to push a migrant away from a community, while positive or pull factors tend to draw the migrant to a community. The migrant weighs the positive and negative costs of the move and determines the expected benefits from the moving or not moving in the migration decision making process (Lee 1966). These factors or variables may be economic, such as employment opportunities or cost of living, but may also include psychological attachment, human capital 
improvements, climate, recreational opportunities, or other factors the migrant considers important in making a decision to migrate (Goetz 1999; Greenwood 1985; Heuer 2004). This illustrates that those migrating respond to negative or "push" factors at the place of origin and positive or "pull" factors at the destination. The decision to move to a new community is made when the factors or the perceived benefits from a move are greater than the costs or negative at the place of origin (Lee 1966; Goetz 1999).

Push and pull migration decision variables vary for each individual considering migration. Variables such as employment opportunities, salary, family relationships, or any infinite number of other variables can be part of the migration decision process. Research does show that there are a number of life cycle factors that are common to the migrant population. Life cycle factors are events that are common to a substantial portion of a population. A cycle normally takes place during a specific period or sequence in one's individual life. Life cycle factors like age, marriage, race/ethnicity, education and economics are just four of the cycle factors that are important in determining migration. Researchers have found a relationship between life cycle events in an individual's life and the propensity to migrate (Mincer 1978).

\section{Neoclassical Economic Theory}

Migration provides a social mechanism for the redistribution of population. The population adjusts to changes in the economy and the workforce within a region (Haurin and Haurin 1988). During periods of national growth, the population migration change has less of an impact on local economies than during other economic phases (Greenwood 1985). Migration provides a ready workforce for the receiving areas while relieving 
unemployment in the place of origin (Logan 1978). Regions with higher rewards for training and skills tend to attract more skilled workers (Borjas, Bronars and Trejo 1990).

Economic circumstances, spatial factors and area amenities are also important to the cost benefit analysis in a family's migration calculation (Lee and Roseman 1999). Areas rich in amenities, such as the western and southern states, are more attractive for migrants (Greenwood et. al 1991) States with a seacoast or low average wind speed tend to have less migration of college graduates (Kodrzycki 2001). States with large populations are less likely to lose college graduates to migration (Kodrzycki 2001). Urban areas attract younger and more highly educated and skilled workers from surrounding rural areas (Fulton, Guguitt and Gibson 1997). Income levels of an area are also an inducement for migration to an area. Areas with larger populations tend to draw additional population through migration (Cadwallader 1992; Hung, Prazwm and Wohlgemuth 2002; Heuer 2004).

While being poor or unemployed can increase migration, public assistance programs act as a deterrent to migration to other areas (Baryla and Dotterweich 2001). The poor tend to fill lower skilled employment positions that pay minimum wage. When the poor migrate, there is strong evidence that differences in neighboring state minimum wage laws influence their migration location decision (Cushing 2003). The perceived net benefit from the higher minimum wage and more complete minimum wage coverage are likely to attract this sector of migrants to neighboring states with a higher minimum wage (Cushing 2003).

Economic theories of migration view the migration behavior as being based on the assumption that migration takes place in response to economic opportunities (Sjaastad 
1962). These theories view migration as an action to maximize the individual and household well-being based on a comparison of income opportunities at alternative locations. Migration occurs when differences in labor wages or employment opportunities at one location become great enough to encourage the investment in the initial costs of migration for the anticipated benefits that will occur over time in a new location. The neoclassical economic approach assumes that migration represents an investment not just in dollars and cents but also an investment in human capital. This investment in migration may not be immediately realized but accrues over time (Sjaastad 1962; Todaro 1969). Neoclassical economic theory predicts that with all else being equal, migration will be greater for individuals living in communities where wages are low and prospects for income growth are poor, rather than for individuals living in communities that have favorable economic opportunities. The theory is concerned with the economic problems of labor mobility, economic growth and man power reallocation. Generally these theories ignore the empirical data on the social variables relationship to migration (Mangalam and Schwarzweller 1968).

\section{Social Network Theory}

While the neoclassical theory seeks to explain migration in terms of capital or labor supply and demand, social network theory explains migration in terms of family, group and community networks. Social ties are a powerful predictor of migration behavior. Migrants looking to move to a new area tend to minimize the risks associated with migration through capital garnered by social networks. Social network migration depends heavily on social capital (Yaukey, Anderton and Landquist 2007). This support may take the form of information for the employment and housing opportunities, or it can 
be more substantial support in the form of job search references, emotional support, a place to stay_ or the network may even provide financial support (Massey 1990). The assistance provided by social networks is location specific. Community migration streams tend to develop that direct new migrants to a few destinations where earlier migrants have established a foothold in a community and labor market.

Network-led migration tends to be self-perpetuating. As the knowledge and experiences of migration become known within the community, the risk is reduced for other potential migrants that remain at home (Yaukey, Anderton and Landquist 2007). As more members of a community gain experience with the new migration community there is the formation of a culture of out-migration in which life-style and mobility aspirations are tied to the new community. As the size of the network increases it takes on a momentum of its own as the size of the migrating population grows in the new community (Massey 1990).

\section{Stem and Branch Migration}

Stem and branch migration is a form of social network migration based upon the concept of the family unit. Stem and branch migration is based on the work of Frederic LePlay (1878), who perceived the family unit as a basic social unit or network. His view stated there was only one type of family and that the differences in the strength of the family accounted for three types of structures of families. The first structural type was the patriarchal-type family, which is concerned with keeping the family together and preserving traditional family boundaries. In this model, married children live near the family and remain under its dominance (Scharzweller, Brown and Mangalam 1971). This is a family dominated by close ties, and, although it offers stability, it does not offer the 
mobility needed in an industrial society (Parsons 1951). Because of the close family ties and the need for the physical presence in the patriarchal-type structure, this family structure tends to discourage migration (Scharzweller, Brown and Mangalam 1971).

LePlay's second type of family structure is the unstable-type of family. This type of family encourages individualism that frees the individuals from family obligations. There is little attachment to the family home place, history and traditions. In this type of family, the individual is dependent upon themselves, and outside agencies or government to assist in time of adversity (Scharzweller, Brown and Mangalam 1971). The unstabletype family is a weak system, where community members will suffer in an industrial society (Parsons 1951). Because this family structure does not offer support, it places risk on individual members, and it therefore encourages migration (Scharzweller, Brown and Mangalam 1971).

The famille-scuche is LaPlay's third type of family structure. This stem family combines the virtues of both the patriarchal-type and unstable family type structures. This family type consists of a parental household (the stem) as a natural network and a number of individuals (the branches) who leave the household to become part of the wider community. The stem family preserves the family structural unit, and it insures that the branch has a safety net of support in case of failure. The branch family adjusts to new opportunities, while support from the stem family lessens the risk of migration (Scharzweller, Brown and Mangalam 1971; Zimmerman and Framton 1935).

Stem and branch migration is underpinned by a strong family network. The stem family provides protection during the migration process. The individual undertakes migration with family support of the stem family. While the individual may move to a 
new area, their ties remain to the home place where the stem of the family resides. This place may be a parcel of land, a house, and/or a community or kinship network that the migrant can rely on as the place to go in time of need for support. If the move to the new location does not work, the migrant can always return to the stem (Scharzweller, Brown and Mangalam 1971).

A branch family structure also supports the migration process. Branch family members that have relocated before the new migrant help to lower the risk to subsequent family members in that new location. Once established in their new location, branch family members can provide direct support, such as a temporary place to stay, employment references, social introductions or other support to help the newer resident settle into the community. After the migrant has settled into the new community the branch family continues to provide support though social networks and psychological support. This branch support does not necessarily come from an immediate family member, but can come from distant family members or acquaintances from the home place community (Scharzweller, Brown and Mangalam 1971).

\section{Migration Clustering}

Branch migration tends to happen in clusters which minimize risk to the new arrivals in a community (Scharzweller, Brown and Mangalam 1971). New migrants tend to move to a location where earlier migrants have settled. An area's racial and economic homogeneity has an impact on the selection of a migration destination. Racial minorities and ethnic groups comprise a large portion of the population in the United States, but their location settlement is unevenly distributed (Frey and Liaw 2005). There is a tendency for people to move to areas with populations similar to them in racial 
distribution, religious beliefs, and nationality characteristics (Cadwallader 1992; Frey and Liaw 2005). Different racial and ethnic groups tend to move to areas with high concentrations of their own racial or ethnic group (Baryla and Dotterweich 2001; Frey and Liaw 2005; Greenwood and Glormey 1971).

Evidence seems to support this community clustering of racial and ethnic groups. Southerners from the same area who moved north during the great migration tended to cluster in the same destination cities. Destination city choice was determined by race, with blacks clustering in cities--different from the white community clustering even though they were from the same area (Tolnay, Adelman and Crowder 2002). In recent studies Appalachians who leave the mountains tended cluster in communities based established migration patterns. (Alexander 2005; Obermiller and Howe 2000; Obermiller and Howe 2001; Obermiller and Howe 2004; Scharzweller, Brown and Mangalam 1971). Studies of regional migration in the United States have shown that migrants from the mid-west tend to move to Arizona and New Mexico. The South, which had been loosing population to the north since the turn of the century, has gained population with a change in migration streams as rural southerners migrate to new communities in the south, and northerners migrate south. Clustering seems to be present in the new migration patterns (Frey 2004).

\section{Community}

Tönnies perceived community to be a tight and cohesive social entity of the larger society, where social interaction takes place. Family and kinship, according to Tönnies, were the perfect expressions of community; however, he postulated that place or beliefs could have shared characteristics that could also result in community or what he called 
"gemeinschaft" (Tönnies 2002). Internal migration research rarely collects information on community other than the variables differentiations between rural and urban communities. Community, however, can give insight into migration, since it is the place where an individual lives, and it encompasses the social groups and institutions where individuals interact (Mangalam and Scharzweller 1968). Community provides a common set of characteristics that establishes one community's residents apart from residents of other communities and confers status upon individual community members (Kramer 1962). This leads to status communal relationships.

Weber argues that status communal relationships are based on solidarity resulting from the emotional or traditional attachments of participants within a given community. People are born into a family, which is the initial determinant of social status that affects life chances. Social status is conferred by the community. It is based upon esteem or honor placed on an individual or family by the community. Property ownership is not always a status qualification, yet it can be a regular determinate. In a community, property and property less people can belong to the same status group. While class is based on economic markets, status is not purely determined by economics but is also the result of social relationships. Status is determined by any quality that socially is valued or not valued by a community. Honor can be ascribed to abilities, outstanding achievement or accomplishments. Meanwhile, not living up to ordinary standards or participating in behavior that is disapproved of by the community can bring dishonor and lower status, thereby ranking an individual as being equal or not equal (Weber, Runciman, Matthews 1978). 
Individuals, groups and communities have status based on the honor that is bestowed up them. Status communities emerge from the social ranking of individuals, family lineage, networks, groups and institutions within a community. The status classification itself gives honor and prestige, creating a hierarchy of higher to lower status communities. A gated community will usually have more status than a low income community. Within the gated community and the low income community there will also be a hierarchical community. Those with the most honor and prestige are the status community. This community may be a community of economic wealth and other economic capital, but the honor may be based on the human and social capital that the community has acquired (Kramer 1970).

Migration is a self selection process; those having human and economic capital are most likely to migrate (Blau and Duncan 1987; Cadwallader 1992). The community and place into which a person is born affects their future employment chances in life. The place of birth increases the chances that an individual will live in a community and the advantage the place of birth offers (Blau and Duncan1987; Weber 1978). Those who participate in distance migration are predominantly part of the status community. They tend to have the human, social and economic capital associated with the status community (Blau and Duncan1987; Schwarzweller, Brown and Mangalam 1971). This does not mean that others in the community do not relocate, but they are more likely to relocate a shorter distances into neighboring communities near where they live (Schwarzweller, Brown and Mangalam 1971). Because the migrant is able to convert the capital to status privileges at the new location, migrants tend to be more successful and upwardly socially mobile than their peers who remain in the area of their birth. They are 
not held back by social obligations or the limited opportunities that are imposed on individuals living in their birth area. Migrants living away from their place of birth are free from the restraints and influences that the childhood environment imposes on a career. This is explained by the fact that migration is selective of those with a higher potential for occupational achievement, superior social origins, education and work experience--all characteristics needed for success and occupational status mobility. The selective process allows those from the status community to move to places where their skills to succeed provide the greatest opportunities for success (Blau and Duncan 1967).

Those who migrate have higher levels of social capital and were better prepared to migrate (Adelman and Tolnay 2003). The communities where migrants move tend to be similar in status, ethnic and racial make-up to the community from which they originally migrated (Obermiller and Maloney 2002). Rural migrants tend to migrate to cities in areas where there are individuals of similar social status. Migrants from the city tend to move shorter distances to the suburbs in communities where those of similar social status reside (Blau and Duncan 1967). With stem and branch, migration is supported by friends and family back home and those who have previously migrated. The status of the individual is transferred from the sending community because the individual moves within the same community in two different locations (Schwarzweller, Brown and Mangalam 1971). Even with the rise in occupational status that tends to follow migration, the migrants tend to stay in or move close to communities of their peers (Blau and Duncan 1967; Obermiller and Maloney 2002; Schwarzweller, Brown and Mangalam 1971). 


\section{RESEARCH HYPOTHESES}

This research utilizes the now classical macrostructure analytical approach used by Blau and Duncan (1967) in their study of the occupational status achieved by migrants. The approach makes use of community types as a macrostructure in the analysis of occupational data to determine the outcomes of migration. Using the macro structural approach, the researcher investigates the socioeconomic status of the community where an individual lived at age 14 and then compares the area with the receiving migration community where the movers lived at mid career in their life cycle between the ages of 37 and 45 .

Not all communities are equal, since they are routinely ranked for socioeconomic status and livability. The U.S. Census Bureau periodically releases reports that identify and rank counties on the income levels of the residents (U.S. Census Bureau 2005; U.S. Census Bureau 2005b). Those counties that rank higher in income usually offer better schools, better public services and higher levels of social capital to their residents (Lin 2001). Since most migration is based upon housing preference and economic opportunity (U.S. Census Bureau 2004), it is logical to assume that those who migrated from the location where they lived in 1979 to a new location in 2002 were looking for communities that provided better socioeconomic opportunities. This study will examine the role the socioeconomic status of origin community on migration outcomes. The study will determine if there is a relationship between the communities where respondents to the NLSY79 lived based upon two time points—-where respondents lived in 1979 and then 23 years later in 2002 .

This research will test the hypotheses that: 
1) Socio-economically community differences at age 14 will influence where movers live during middle age.

2) The migration tendency for movers in 2002 will be towards moving towards desirable communities which offer higher socioeconomic standards of living.

3) College graduates will be more likely to move from less desirable communities to desirable communities with low unemployment and higher median income levels.

\section{DATA AND METHODS}

The NLSY79 Survey is a product of the U.S. Bureau of Labor Statistics (BLS). It is a general-purpose survey that represents an entire age cohort that was born between 1957 and 1965. The primary purpose of the NLSY79 is to collect data on the participants' labor force experience, labor market attachment and investment in educational training (Frazis and Speletzer 2005). The survey originated in 1979 with a representative nation sample of 12,686 young men and women between the ages of 14 and 22 . The median year of birth for those participating in the NLSY79 study is 1960. In 2002, the men and women in the survey ranged in age from 35 and 43 years old. Between the years of 1979 and 1994, respondents were sampled on a yearly basis. Then in, 1996, the survey was changed and interviews were conducted biannually. By 2004, due to a relatively low attrition rate, there were still 7,724 of the original interviewees participating (Bureau of Labor Statistics 2006).

For migration research, the availability of geocoded NLSY79 allows researchers to undertake longitudinal or cross-sectional research over a period of years. This data set is useful for migration research because it provides Federal Information Processing Standard (FIPS) codes for place of birth, residence at age 14 and each move since 
enrollment in the survey. Other surveys that contain migration information, like the Current Population Survey (CPS), also provide place location information; however, the participants surveyed via the CPS are rotated in and out of the program every two years, making it impossible to track participants for long periods of time. The Decennial Census also collects the location of individual residence five years prior to interview, but this data is collected for only one point in time. Like the CPS, the Decennial Census presents cross sectional data for only one point in time, and it is not possible to follow an individual over an extended period of time through cycles of life.

In contrast, the NLSY79 survey has the advantage of being a longitudinal survey that has continued to gather information on survey participants for the 23 years. The value of this survey is that it has followed a group of individuals through the cycles of life from youth to middle age. However, one drawback of the data is that it contains fewer participants than many other data sets that contain migration information, like the Decennial Census. The NLSY79 is also is a static data set. Since no new participants are being added to the survey, no recent immigrants are included in the sample.

\section{Measurements}

\section{Dependent Variables}

This study will measure the effect of the dependent variables on long term migration outcomes. There are two measurable elements of the dependent variables. The first measure is whether a move occurred between age 14 and 2002. If the FIPS code for place of residence in 2002 of a respondent is different than the FIPS code place of residence at age 14 , then migration has taken place. This is a simple move or "no move" determination $(0=$ No Move, $1=$ Move $)$. Those who were living in the same county in 
2002 as they lived at age 14 were coded as "No Move". Those that were living in a different county in 2002 than at age 14 are considered to have made a migration move. The data was selected for those for whom a migration was recorded. The second determinate of the dependent variable is the geospatial variable for county median family income for the county of residence in 2002 . The median income for each county was determined by matching the survey participants FIP's code for each county's corresponding FIPs code in the U.S. Census Bureau's, 1994, City County Data Book. The individual counties median income was found within this document as well as the national median income. It was then determined if the individual counties median income was above or below the national median income and the county's median income was indexed as being above or below the national median income level.. Median income is a standard measurement of wealth within a community and is used to determination county eligibility for many federal programs.

. This second element of the dependent variables examines the quality of the intercounty moves. This measure of migration is used to determine the quality of movement between counties and is based on the desirability of key geospatial socioeconomic indicators. Since most internal migration in the United States is a move for more desirable housing and/or economic reasons, it is logical to assume that movers will try to move to receiving communities that have a higher social status. A move from a sending community with a lower status to a higher status community would be a desirable move, from an undesirable to a desirable area. A move from a higher status community to a lower status community would be downward mobility move form a desirable to undesirable geospatial county. 


\section{Independent Variables}

The independent variables for this study will be based on the geospatial variable based on county of residence and human variables for residence in the NLSY'79 longitudinal survey. These variables, county median family income, county per capital income, county percentage of families living below the poverty level, and county unemployment rates are all based on the county of residence for survey participants at age 14. These variables are based on the county level data and reflect the socioeconomic health of a county. These variables per capital income above the national level, percentage of county families living below the national poverty level and the county unemployment level below the national average would all be individual desirable indicators for a community. Communities with higher desirable socioeconomic indicators tend to be desirable communities in which to live and offer their resident's opportunities and amenities those counties that with undesirable indicators are often unable to provide.

The desirability or undesirability of a community is measured by socioeconomic indicators and whether the counties are above or below the national median county level. The geocoded NLSY79 contains unemployment rates, percent of families living below the poverty level, per capital income and median family income for the county where the respondent was reported living for each interview period as part of the dataset (Bureau of Economic Analysis 1994; Bureau of Labor Statistics 2006b). This data will be compared to the national median for each of the aforementioned variables to determine if a county of residence are above or below the national median $(0=$ below, $1=$ above) $($ U.S Census Bureau 1979; U.S Census Bureau 1996; Bureau of Labor Statistics 2006b). Median income and per capital income above the nation national median are considered to be 
desirable. The opposite is true of poverty and unemployment rates where a percentage above the national rates is undesirable for these dependent rates. Then by measuring the dependent variables as desirable and undesirable the labels are able to transpose to the variables the socioeconomic rating for the geospatial community.

In addition to these four independent variables cited above additional human capital and geospatial variables will be examined through binary regression analysis to determine the variables relationship in influencing the outcomes of migration. These variables include lifecycle characteristics for the individual respondents. The variables for Family below the poverty level in $1979(0=$ family not in poverty, 1 family in poverty $)$, Sex $(0=$ female, $1=$ male $)$, race $(0=$ white and other, $1=$ black $)$ and ethnicity $(0$ $=$ Non Hispanic, $1=$ Hispanic $)$. Years of school $(1=$ less than High School, $2=$ High School, $3=$ Some College, $4=$ four years of college, $5=$ greater than 4 years of college) will provide information on educational levels. Life cycle variables include marital states $(0=$ not married, $1=$ married $)$, and children at home in $2002(0=$ no children, $1=1$ child, $2=2$ children, $3=$ three or more children).

\section{Geographic Control}

For the geographic variables the research will utilize the United States Department of Agriculture's Rural-Urban Continuum Codes. In this study, the codes will be used to determine if a county is rural or Metro in both measurement periods $(0=$ nonmetro area of less than $250,000,1=$ metro area greater than 250,000$)$. This variable is determined by the U.S. Department of Agriculture and is a recognized as the standard for measuring if a county is a rural or urban county at all levels of government (Economic Research Service 2003; Economic Research Service 2003; Economic Research Service 
2004). In addition each of the dependent variables is measured independently against the independent metro/rural variables at age 14 in order to determine relationships to community population size. This indicator along with the spatial variables county median family income, county per capital income, county percentage of families living below the poverty level, and county unemployment rates control for spatial migration indicators.

\section{ANALYTICAL STRATEGY}

In 1979 when the NLSY79 began, 12,686 respondents were participating in the study. In 2002 there were 7,721 respondents interviewed for the longitudinal study. The data in the research is structured to show difference in residence for the two observation periods 23 years apart. The study will first determine if a migration had taken place for the individual. This will be done by an analysis of the county FIPs code for study participants at age 14 and then the reviewing if there was a change in FIPs code in 2002. Thus, it can be determined if migration has taken place. If migration has taken place, the nature of the migration will be further analyzed to determine those variables which contribute to movement towards migration to desirable communities.

The NLSY79 data was analyzed using Statistical Package for the Social Sciences (SPSS). Using FIPs codes for age 14 and the year 2002 those who changed county of residence are selected out of the total NLSY79 database for analysis. Only those who were not living in the same county of residence at age 14 and 2002 were selected for the study database. After selecting from the data set for only those who changed county of residence during the study period the data was tested for the relationship between the dependent variable and the independent variables. 
Table 1. Descriptive Statistics for Dependent Variable Measurements

\begin{tabular}{|l|l|l|l|l|l|}
\hline & Description & Mean & SD & Min & Max \\
\hline $\begin{array}{l}\text { County Median Family } \\
\text { Income for the County of } \\
\text { Residence in 2002 }\end{array}$ & $\begin{array}{l}\text { County Median Family Income for } \\
\text { Study Participants Above National } \\
\text { Median (0 = Undesirable, } 1= \\
\text { Desirable) }\end{array}$ & .58 & .494 & 0 & 1 \\
\hline
\end{tabular}

Through binary regression the study determines the variables that lead to migration to desirable counties as opposed to undesirable communities whose median income is below the national median incomes. The independent variable can be divided into two distant classifications: those attributes that contribute to an individual's human capital, such as sex, race and income, and spatial variable such as rural/urban and county level socioeconomic measurements that measure the effect of community on the migration outcomes.

The study then uses cross tabulations to show migration patterns for NLSY'79 participants. The cross tabulation analysis measures the dependent variable desirability of the median income of county of residence against the independent variable desirability of the county of residence of the median income of the county of residence at age 14 . Then the additional demographic and geospatial variables are integrated into the analysis. This creates a layered cross tabulation wherein the demographic and geospatial independent variables are nested within the main independent variables. The resulting cross tabulation table allows testing of the secondary independent variable against the dependent variable and the primary independent variables. Each cross tabulation data set is tested using chi-square significance tests. Each of the independent variables is tested against the main dependent variable. 
Table 2. Descriptive Statistics for Independent Variable Measurements

\begin{tabular}{|c|c|c|c|c|c|}
\hline & Description & Mean & $S D$ & Min & Max \\
\hline Gender & $\mathrm{R}$ is Male $(1=$ Male, Female 2$))$ & 1.5 & .500 & 1 & 2 \\
\hline Race & $\begin{array}{l}\mathrm{R} \text { is race }(0=\text { White and Other, } \\
1=\text { Black })\end{array}$ & .312 & .463 & 0 & 1 \\
\hline Ethnicity & $\begin{array}{l}\mathrm{R} \text { is race/ethnicity }(0= \\
\text { Non Hispanic, } 1=\text { Black) }\end{array}$ & .162 & .368 & 0 & 1 \\
\hline Education 2002 & $\begin{array}{l}\text { R's Education }(1=\text { Under } \\
\text { High School Education, } 2= \\
\text { High School Education, } 3= \\
\text { Some College, } 4 \text { Years of } \\
\text { College, } 5=\text { More Than } 4 \\
\text { Years of College }\end{array}$ & 2.78 & 1.282 & 1 & 5 \\
\hline Marital Status 2002 & $\begin{array}{l}\mathrm{R} \text { is Married at time } \mathrm{t}(1= \\
\text { Never Married, } 2=\text { Married, } \\
\text { Spouse Present, } 3=\text { Other })\end{array}$ & .602 & .489 & 0 & 1 \\
\hline $\begin{array}{l}\text { Number of Children at } \\
\text { Home }\end{array}$ & $\begin{array}{l}\text { Number of Children in } \mathrm{R} \\
\text { household living at home at } \\
\text { time } \mathrm{t}(0=\text { No Dependents, } \\
1=1 \text { Dependent, } 2=2 \text { Dependents } \\
3=3 \text { Dependents or More })\end{array}$ & 1.31 & 1.114 & 0 & 3 \\
\hline Family Poverty Status & $\begin{array}{l}\mathrm{R} \text { is Family Poverty Status }(0=\text { Not } \\
\text { in Poverty, } 1=\text { In Poverty) }\end{array}$ & .22 & .415 & 0 & 1 \\
\hline $\begin{array}{l}\text { Lived in Rural or } \\
\text { Urban area at } 14\end{array}$ & $\begin{array}{l}\text { R's County of Residence at age } 14 \\
\text { and then in } 1979(0=\text { Non Metro, } \\
1=\text { Metro })\end{array}$ & .59 & .492 & 0 & 1 \\
\hline $\begin{array}{l}\text { County of Origin } \\
\text { Median Family Income } \\
\text { at Age } 14\end{array}$ & $\begin{array}{l}\text { County Median Family Income for } \\
\text { R's County of Residence at age } 14 \\
(0=\text { Undesirable, } 1=\text { Desirable })\end{array}$ & .44 & .496 & 0 & 1 \\
\hline $\begin{array}{l}\text { County of Origin Per } \\
\text { Capital Income at Age } \\
14\end{array}$ & $\begin{array}{l}\text { County Median Family Income for } \\
\text { R's County of Residence at age } 14 \\
(0=\text { Undesirable, } 1=\text { Desirable })\end{array}$ & .45 & .497 & 0 & 1 \\
\hline $\begin{array}{l}\text { County of Origin } \\
\text { Percentage of Families } \\
\text { Poverty Level at Age } 14\end{array}$ & $\begin{array}{l}\text { County Percentage of Families } \\
\text { Below the Poverty Level for R's } \\
\text { County of Residence at age14 }(0= \\
\text { Undesirable, } 1=\text { Desirable })\end{array}$ & .519 & .499 & 0 & 1 \\
\hline $\begin{array}{l}\text { County of Origin } \\
\text { Unemployment Rate at } \\
\text { Age } 14\end{array}$ & $\begin{array}{l}\text { County Level of Unemployment for } \\
\text { R's County of Residence at age } 14 \\
(0=\text { Undesirable, } 1=\text { Desirable })\end{array}$ & .549 & .497 & 0 & 1 \\
\hline
\end{tabular}




\section{RESULTS}

The NLSY79 data (Table 3) shows that $70 \%$ of those participating in the study have changed county of residence at least one time between age 14 and the 23 years of age. Of those who moved from county of residence at age $14,25 \%$ were repatriated to the county of residence at age 14 by the 2002 study period. Study participants living in a different county of residence from age 14 (Table 5) is 52\% for the 2002 interview period. The total migration from county of residence at age 14 has been a gradual migration with $9.6 \%$ to $20.7 \%$ of the study participants changing their county of residence in any one interview period. The data that is available does show that the number of moves for participants ranged for 1 to 15 county relocations with a 3.27 mean for the inter-county moves that are accounted for in the NLSY79. The precise number of intra-county moves can not be accounted for by the NLSY79, because of moves between intervening interview periods or the interviewers were unable to establish contact with study participants for a particular study period. When these variables are viewed together they tend to point to the fact that once an individual has migrated from the county they lived during adolescence they are unlike to return to that location in successive years.

Table 3. At Least One Change in County of Residence Between Age 14 and 2002

\begin{tabular}{|l|c|c|}
\hline & Frequency & Percent \\
\hline Never Moved & 2218 & 30 \\
\hline Move at Least 1 Time & 5164 & 70 \\
\hline Total & 7382 & \\
\hline
\end{tabular}


Table 4. Change in County of Residence at Age 14 and 2002

\begin{tabular}{|l|c|c|}
\hline & Frequency & Percent \\
\hline No Move & 3493 & 47.3 \\
\hline Move & 3889 & 52.7 \\
\hline Total & 7382 & \\
\hline
\end{tabular}

\section{Cross Tabulations for County Median Income 2002}

The frequency analysis in Table 5 shows a comparison of the dependent variable “County Median Family Income for the County of Residence in 2002 ” with the independent Human Capital and Spatial Variables. The cross tabulations for is insignificant just as was found in the binary logistic regression. This variable has a frequency of nearly $50 \%$ male and $50 \%$ female that is affecting the significance of the variable.

The human variable shows that $60.1 \%$ of whites and other population and $52.8 \%$ of blacks lived in desirable median income communities in 2002. The variable for ethnic shows that $52.8 \%$ of Hispanics lived in desirable communities, while $51.5 \%$ of non Hispanics lived in undesirable counties meaning that proportionately Hispanics represent a higher proportion of this ethnic population living in desirable counties than other non Hispanic groups.

The human capital variables related to marriage show that those who are married are $4.1 \%$ more likely to live in a higher income county and other marital groups. The children at home variable is near $56 \%$ of those having no children, one child or three or more children living at home living in desirable communities while $43 \%$ lived in undesirable communities. The cohort of 2 children show a $5 \%$ difference from the other children at home variable with $61 \%$ of families with two children living in a county 
above the median income in 2002 and $38.9 \%$ living in counties below the national median income level.

Educational variable show that $71.3 \%$ of those with less than a high school and $69.1 \%$ of those with educational attainment of a high school degree lived in counties with a median income below the national median income level. This pattern follows for the cohorts of some college (56.8\%), college degree $(52.5 \%)$ and graduate or professional degree (48\%) which shows a negative slope as education increases. A positive slope can be found when comparing less than high school education (28.7\%) to greater than 4 years of college $(52 \%)$. As the education level increase the study participants were more likely to live in counties with median incomes above the national level.

The cross tabulation show that the majority of those who live in desirable median income communities $(60.2 \%)$ were from families with incomes above the poverty level at age 14. Those who at age 14 had a family income that was above the poverty level but lived in counties in the year 2002 with median incomes below the poverty level was $39.8 \%$. Of the population whose family income was below the poverty level at age 14 , $47.1 \%$ of the population lived in counties with median incomes above the national median income.

The cross tabulation for geospatial spatial related variables are related to the place where the study participants lived at 14 years of age. This data show that there is a nearly even 50/50 split of those who lived in rural areas to move to desirable and undesirable median income counties in 2002. Those who lived at 14 years of age in a metro area were more likely to move to a desirable county. Over $63 \%$ of this population moved to desirable counties in 2002 and only $36 \%$ moved to undesirable counties. The median 
income variables for both age 14 and the year 2002 show that $67 \%$ of those who lived in desirable communities at age 14 also lived in desirable communities in 2002. This show little downward mobility with less than $40 \%$ moving to undesirable counties for the median income variables. The median income variables for those living below the median income show a nearly 50/50 split between moving to a desirable and undesirable community in 2002 .

Of those living in counties with poverty rates below the national poverty level at age 14 . Nearly $65 \%$ lived in counties with median incomes below the national median income in 2002 . Only $35 \%$ of this population moved to the desirable median income counties. For those who live in the desirable counties at age 14 the population was evenly split between the desirable and undesirable communities. The unemployment data at age 14 shows that overwhelmingly those who migrated from areas of high unemployment toward counties in 2002 with desirable median incomes. Only $38.8 \%$ of this population migrated to counties with undesirable median incomes.

Table 5. County Median Family Income for the County of Residence in 2002

\begin{tabular}{|l|l|l|}
\hline & \multicolumn{2}{|c|}{$\mathrm{N}=3830$} \\
\hline & Undesirable & Desirable \\
\hline Gender * & & \\
\hline Male & 41.7 & 58.3 \\
\hline Female & 42.7 & 57.3 \\
\hline Race & & \\
\hline White and Other & 39.9 & 60.1 \\
\hline Black & 47.2 & 52.8 \\
\hline Race/Ethnic & & \\
\hline Non Hispanic & 51.5 & 48.5 \\
\hline Hispanic & 47.8 & 52.2 \\
\hline Marital Status & & \\
\hline Single, Other & 44.7 & 55.3 \\
\hline
\end{tabular}




\begin{tabular}{|c|c|c|}
\hline Married & 40.6 & 59.4 \\
\hline \multicolumn{3}{|l|}{ Children at Home } \\
\hline 0 & 43.3 & 56.7 \\
\hline 1 & 43.7 & 56.3 \\
\hline 2 & 38.9 & 61.1 \\
\hline 3 or More & 43.7 & 56.3 \\
\hline \multicolumn{3}{|l|}{ Education Level 2002} \\
\hline$<$ High School & 71.3 & 28.7 \\
\hline High School & 69.1 & 30.9 \\
\hline Some College & 56.8 & 43.2 \\
\hline 4 Yrs College & 52.5 & 47.5 \\
\hline$>4$ Yrs College & 48.0 & 52.0 \\
\hline \multicolumn{3}{|c|}{ Family Poverty Status 1979} \\
\hline Above Poverty Level & 39.8 & 60.2 \\
\hline Below Poverty Level & 52.9 & 47.1 \\
\hline \multicolumn{3}{|c|}{$\begin{array}{l}\text { Lived in Rural or Urban area } \\
\text { at } 14\end{array}$} \\
\hline Rural & 50.2 & 49.8 \\
\hline Metro & 36.5 & 63.5 \\
\hline \multicolumn{3}{|l|}{$\begin{array}{l}\text { County of Origin Median } \\
\text { Income Age } 14\end{array}$} \\
\hline Desirable & 33.0 & 67.0 \\
\hline Undesirable & 49.6 & 50.4 \\
\hline \multicolumn{3}{|c|}{$\begin{array}{l}\text { County of Origin Per Capital } \\
\text { Income at Age } 14\end{array}$} \\
\hline Desirable & 35.0 & 65.0 \\
\hline Undesirable & 48.0 & 52.0 \\
\hline \multicolumn{3}{|c|}{$\begin{array}{l}\text { County of Origin Percentage } \\
\text { of Families Poverty Level at } \\
\text { Age } 14\end{array}$} \\
\hline Desirable & 49.8 & 50.2 \\
\hline Undesirable & 64.9 & 35.1 \\
\hline \multicolumn{3}{|c|}{$\begin{array}{l}\text { County of Origin } \\
\text { Unemployment Rate at Age } \\
14\end{array}$} \\
\hline Desirable & 46.4 & 53.6 \\
\hline Undesirable & 38.8 & 61.2 \\
\hline
\end{tabular}

$\mathrm{P}>.05=*$ 


\section{Living in an Above the Median Income County in 2002}

The results of binary logistic regression analysis are shown in Table 6, Table 7 and Table 8. Table 6 shows the results the dependent "County Median Family Income for the County of Residence in 2002" relationship when tested against each of the twelve independent variables. Table 7 shows the results of testing the dependent variable and the independent variables that are related to human capital and community spatial variables. The variable "County of Origin Median Income Age 14" was excluded from this table because of its correlation to the "County Median Family Income for the County of Residence in 2002". Table 8 adds the variable "County of Origin Median Income Age 14 " to the models so that to test the variables relationship to the human and the other independent spatial variables.

The binary logistic regression was used to test each of the independent variables “Marital Status", "Race”, "Ethnicity”, "Family Poverty Level at 14”, and "Educational Level 2002" were found to be significant human variables. "Gender" and "Number Children at Home" were found to be not significant for binary logistic regression. The spatial variable "Lived in rural or urban area at 14", "County of Origin Per Capital Income at Age 14", "County of Origin Percentage of Families Poverty Level at Age 14”, "County of Origin Unemployment Rate at Age 14" and "County of Origin Median Income Age 14" were all found to be significant when binary logistic regression was used for analysis. 
Table 6. Binary Logistic Regression - County Median Family Income for the County of Residence in 2002

\begin{tabular}{|l|c|c|c|c|}
\hline & \multicolumn{4}{|l|}{$\begin{array}{l}\text { County Median Family Income for } \\
\text { the County of Residence in 2002- } \\
\text { Desirable }\end{array}$} \\
& B & S.E & $\begin{array}{c}\text { Odds } \\
\text { Ratio }\end{array}$ & Sig \\
\hline & & & & \\
\hline $\begin{array}{l}\text { County of Origin Median Income Age } \\
\text { 14 - desirable }\end{array}$ & 0.691 & 0.069 & 1.997 & 0.000 \\
\hline Gender-Female & -0.040 & 0.065 & 0.961 & 0.544 \\
\hline Marital Status- Married & 0.165 & 0.067 & 1.180 & 0.013 \\
\hline Number Children at Home -3 & 0.026 & 0.029 & 1.027 & 0.371 \\
\hline Race - Black & -0.298 & 0.070 & 0.742 & 0.000 \\
\hline Ethnicity - Hispanic & -0.340 & 0.090 & 0.712 & 0.000 \\
\hline Family Poverty Level at 14 - In Poverty & -0.529 & 0.080 & 0.589 & 0.000 \\
\hline $\begin{array}{l}\text { Educational Level 2002 -Graduate } \\
\text { School }\end{array}$ & 0.267 & 0.027 & 1.306 & 0.000 \\
\hline $\begin{array}{l}\text { Lived in Rural or Urban area at 14 - } \\
\text { Metro }\end{array}$ & 0.564 & 0.067 & 1.768 & 0.000 \\
\hline $\begin{array}{l}\text { County of Origin Per Capital Income at } \\
\text { Age 14 - Above National Per Capital } \\
\text { Income }\end{array}$ & & & & \\
\hline $\begin{array}{l}\text { County of Origin Percentage of Families } \\
\text { Poverty Level at Age 14 - Below } \\
\text { National Poverty Rate }\end{array}$ & 0.540 & 0.068 & 1.716 & 0.000 \\
\hline $\begin{array}{l}\text { County of Origin Unemployment Rate at } \\
\text { Age 14 - Below National } \\
\text { Unemployment Rate }\end{array}$ & 0.621 & 0.067 & 1.860 & 0.000 \\
\hline
\end{tabular}

The result of multivariate logistic regression in Table 7 investigates the relationship of the human capital and the spatial variables in relationship to the Dependent Variable median income of county of residence in 2002. The human capital variables "Gender", "Marital Status" and "Number of Children at Home" were not significant to model A. The significance of "Race" is .059 and is slightly above the .05 significance level is slightly above the $95 \%$ confidence level. The variables "Ethnicity", "Family Poverty Level at 14" and "Educational Level 2002" where found to be significant. "Race", "Ethnicity" and "Family Poverty Level at 14" were negatively 
associated with living in a "Median Family Income for the County of Residence in 2002" that is desirable. "Educational Level 2002" was positively associated with the "County Median Family Income for the County of Residence in 2002”. Blacks are .860 less like to live in a county with median income above the national median income while Hispanics are .824 less likely. If the family was in poverty at age 14 then it is a .724 less likely that the individual will live in a county above the median income level. Education was positively related to the county median income variable. Where family poverty status made it $26 \%$ less like for an individual to live in a county with an income above the median income, Education increased the chances of living in a county with a median income above the national median income. Education increases the chances of living in a desirable median income community by nearly $28 \%$.

"County of Origin Per Capital Income at Age 14", "County of Origin Percentage of Families Poverty Level at Age 14", and "County of Origin Unemployment Rate at Age 14"variable where not significant in Table 6. Model B. The only spatial variable that is significant in this model was "living in a rural or urban area at 14" and the odds ratio is 1.434. Living in a metro area at age 14 increased the chance, by $43 \%$, for "living in a county above the median income in $2002 "$. 
Table 7. Multivariate Logistic Regression for County Median Family Income for the County of Residence in 2002 Excluding County of Origin Median Income Age14

\begin{tabular}{|c|c|c|c|c|c|c|c|c|}
\hline & \multicolumn{8}{|c|}{$\begin{array}{l}\text { County Median Family Income for the County of Residence in } 2002 \\
\text { without County of Origin Median Income Age14 }\end{array}$} \\
\hline & \multicolumn{4}{|c|}{ Model A Human Variables } & \multicolumn{4}{|c|}{ Model B Spatial Variables } \\
\hline & B & S.E & $\begin{array}{l}\text { Odds } \\
\text { Ratio }\end{array}$ & Sig & B & S.E & $\begin{array}{l}\text { Odds } \\
\text { Ratio }\end{array}$ & Sig \\
\hline $\begin{array}{l}\text { County of Origin Median Income Age } \\
14 \text { - desirable }\end{array}$ & & & & & & & & \\
\hline Gender-Female & -0.067 & 0.070 & 0.935 & 0.340 & & & & \\
\hline Marital Status- Married & -0.052 & 0.081 & 0.949 & 0.519 & & & & \\
\hline Number Children at Home -3 & 0.078 & 0.035 & 1.018 & 0.612 & & & & \\
\hline Race - Black & -0.151 & 0.080 & 0.860 & 0.059 & & & & \\
\hline Ethnicity - Hispanic & -0.193 & 0.096 & 0.824 & 0.044 & & & & \\
\hline Family Poverty Level at 14 - In Poverty & -0.292 & 0.089 & 0.746 & 0.001 & & & & \\
\hline $\begin{array}{l}\text { Educational Level } 2002 \text {-Graduate } \\
\text { School }\end{array}$ & 0.245 & 0.029 & 1.278 & 0.000 & & & & \\
\hline $\begin{array}{l}\text { Lived in Rural or Urban area at } 14 \text { - } \\
\text { Metro }\end{array}$ & & & & & 0.361 & 0.101 & 1.434 & 0.000 \\
\hline $\begin{array}{l}\text { County of Origin Per Capital Income at } \\
\text { Age } 14 \text { - Above National Per Capital } \\
\text { Income }\end{array}$ & & & & & 0.084 & 0.150 & 1.088 & 0.575 \\
\hline $\begin{array}{l}\text { County of Origin Percentage of } \\
\text { Families Poverty Level at Age } 14 \text { - } \\
\text { Below National Poverty Rate }\end{array}$ & & & & & 0.164 & 0.123 & 1.178 & 0.182 \\
\hline $\begin{array}{l}\text { County of Origin Unemployment Rate } \\
\text { at Age } 14 \text { - Below National } \\
\text { Unemployment Rate }\end{array}$ & & & & & 0.023 & 0.091 & 1.023 & 0.804 \\
\hline Cox \& Sell R Square & \multicolumn{4}{|c|}{ Model A - .036 } & \multicolumn{4}{|c|}{ Model B - .032 } \\
\hline
\end{tabular}


The analysis of the independent variables in Table 7 indicates that the variables "Race", "Ethnicity", "Family Poverty Level at 14", and "Educational Level in 2002" are significant human capital and lived in rural or urban area at 14 being the only significant spatial variables in the multivariate logistic regression in Table 7. In Table 6 "County of Origin Median Income Age 14" had the highest odd ratio (1.997) associated with “County Median Family Income for the County of Residence in 2002”. In Table 7 the multivariate logistic regression is expanded to include the independent variable "County of Origin Median Income Age 14”.

In Model A the human capital variables are analyzed as in Table 7, Model A with the addition of the independent spatial variable "County of Origin Median Income Age 14". With the addition of this new independent variable "Race" is no longer a significant variable along with the independent variable that were not significant in Table 8, Model A. Hispanics are $-20 \%$ less likely to live in a community with a median income above the national median income level. The odds ratio for "Family Poverty Level at 14" decreases by $4 \%$ with the new odds rations changing from .746 to .785 . The association odds ratio for "Educational Level 2002" varies between the two tables by less than .002. The odds ratio for "County of Origin Median Income Age 14" has a positive odds ratio of 1.808 . While this independent variable is significant, adding this variable does not improve the association of human capital variables to "County Median Family Income for the County of Residence in 2002" found in Table 7.

In Table 8, Model B the independent spatial variable "Lived in Rural or Urban area at 14 " decreases by $8 \%$ with the addition of "County of Origin Median Income Age 14". With the addition of this new variable, however, "County of Origin Unemployment 
Rate at Age 14" becomes a significant variable, with an odds ratio of 1.203. Like in Model A, human capital variables, "County of Origin Median Income Age 14" had the highest odds ratio for the spatial variables selected. Under this model being from a county at age 14 with a median income above the national median income level, increase by $48 \%$ of living in a county in 2002 of living in a county with a median income level above the national median income. With the addition of the "County of Origin Median Income Age 14" variable added to the spatial variable Model B, "County of Origin Unemployment Rate at Age 14" becomes a significant variable with an odds ratio of 1.203 . While this odds ratio for this variable is less than the two other spatial significant variables, it is still within the range of the human capital variables.

Model C combines the human capital form Model A and the spatial variables Model B so that the variable from each model can be compared. In this model "County of Origin Median Income Age 14", "Lived in Rural or Urban area at 14", and "County of Origin Unemployment Rate at Age 14" are the significant spatial variables. The significant human capital variables are "Ethnicity", "Family poverty level at 14", and "education level 2002".

The spatial variable "lived in rural or urban area at 14" has an odds ratio of 1.435 which is highest of the six significant variables in this model. Living in a metro area at age 14 increase the chances of moving to a community with a median income above the national median income increase. The spatial variable "county of residence at age 14 median" is the second most significant variable under this model. Living in a community with an above the national median income level increases the chances of living in a community in 2002 with a median above the national median income by $39 \%$. The third 
significant spatial variable in this model is "County of Origin Unemployment Rate at Age 14". Like the preceding spatial variable this is a positive correlation at 1.160. The human variable "ethnicity" (.806) and "family poverty level at 14" (.803) are negatively correlated to the dependent variable. Living in poverty and being a member of a Hispanic ethnic group decrease the chances of living in a county with a median income above the national median income level. Again the "education level 2002" has a positive correlation to living in a county with a median income above the national level. As the level of education increases the chances of living in a county with an above the national median income level also increases.

The spatial odds for living in a county with an above the national median income are $16 \%$ higher for those who lived in metro area and $12 \%$ for those who lived in an above median income county at 14 than the variable for education level in 2002. In this model these two variables have a greater influence on living in a higher income county than education. Ethnicity and living in poverty as a youth decrease the chance of living in a county above the national median income. 
Table 8. Multivariate Logistic Regression for County Median Family Income for the County of Residence in 2002 Including County of Origin Median Income Age14

\begin{tabular}{|c|c|c|c|c|c|c|c|c|c|c|c|c|}
\hline & \multicolumn{12}{|c|}{ County Median Family Income for the County of Residence in 2002 with County of Origin Median Income Age14 } \\
\hline & \multicolumn{4}{|c|}{ Model A Human Variables } & \multicolumn{4}{|c|}{ Model B Spatial Variables } & \multicolumn{4}{|c|}{$\begin{array}{l}\text { Model C Human and Spatial } \\
\text { Variables }\end{array}$} \\
\hline & B & S.E & Odds Ratio & Sig & B & S.E & Odds Ratio & Sig & B & S.E & Odds Ratio & Sig \\
\hline $\begin{array}{l}\text { County of Origin Median Income Age14 - } \\
\text { desirable }\end{array}$ & 0.592 & 0.074 & 1.808 & 0.000 & 0.396 & 0.137 & 1.486 & 0.004 & 0.334 & 0.143 & 1.396 & 0.020 \\
\hline Gender-Female & -0.058 & 0.072 & 0.943 & 0.417 & & & & & -0.058 & 0.072 & 0.943 & 0.417 \\
\hline Marital Status- Married & -0.041 & 0.083 & 0.960 & 0.623 & & & & & -0.040 & 0.084 & 0.961 & 0.630 \\
\hline Number Children at Home -3 & 0.017 & 0.036 & 1.017 & 0.640 & & & & & 0.015 & 0.036 & 1.015 & 0.674 \\
\hline Race - Black & -0.018 & 0.084 & 0.982 & 0.826 & & & & & -0.054 & 0.086 & 0.947 & 0.529 \\
\hline Ethnicity - Hispanic & -0.218 & 0.099 & 0.804 & 0.027 & & & & & -0.216 & 0.101 & 0.806 & 0.033 \\
\hline Family Poverty Level at 14 - In Poverty & -0.242 & 0.092 & 0.785 & 0.008 & & & & & -0.219 & 0.092 & 0.803 & 0.018 \\
\hline Educational Level 2002 -Graduate School & 0.244 & 0.030 & 1.276 & 0.000 & & & & & 0.245 & 0.030 & 1.277 & 0.000 \\
\hline Lived in Rural or Urban area at 14 - Metro & & & & & 0.306 & 0.085 & 1.357 & 0.000 & 0.361 & 0.090 & 1.435 & 0.000 \\
\hline $\begin{array}{l}\text { County of Origin Per Capital Income at } \\
\text { Age } 14 \text { - Above National Per Capital } \\
\text { Income }\end{array}$ & & & & & -0.098 & 0.107 & 0.907 & 0.362 & -0.093 & 0.111 & 0.911 & 0.491 \\
\hline $\begin{array}{l}\text { County of Origin Percentage of Families } \\
\text { Poverty Level at Age } 14 \text { - Below National } \\
\text { Poverty Rate }\end{array}$ & & & & & 0.206 & 0.119 & 1.228 & 0.083 & 0.126 & 0.127 & 1.134 & 0.320 \\
\hline $\begin{array}{l}\text { County of Origin Unemployment Rate at } \\
\text { Age } 14 \text { - Below National Unemployment } \\
\text { Rate }\end{array}$ & & & & & 0.185 & 0.070 & 1.203 & 0.002 & 0.148 & 0.075 & 1.160 & 0.049 \\
\hline Cox \& Sell R Square & Model A & -.055 & & & Model B & $3-.034$ & & & Model C & -.061 & & \\
\hline
\end{tabular}




\section{CONCLUSION}

The data provides evidence that a higher percentages of individuals from undesirable communities move to desirable communities meanwhile, individuals from desirable communities are less likely to move to undesirable communities. For those who move from desirable to desirable communities the evidence suggests that this movement is by choice. It can also be assumed that movement from undesirable to desirable is by choice since these moves can easily be explained though theories relating economics to migration. Migration to undesirable communities cannot be as easily be explained as economic migration since the mover is moving from desirable to undesirable or undesirable to undesirable. Family socio-economic status most does play a significant role in this migration pattern yet there is evidence that spatial variables also influence this migration pattern. How the place of residence at age 14 affects migration is beyond the scope of this study since only a two by two analysis is employed. Through the use of covariant analysis it would be possible to study further spatial variable affects on migration.

The variables associated with the place of residence during adolescence demonstrate that "County of Origin Median Income Age 12", "County of Origin Unemployment Rate at Age 14" and "Lived in Rural or Urban area at 14" are associated with moving to a desirable community. Those who at age 14 resided in an urban area, from counties with a low unemployment rate and high median income level, are likely to have moved by middle age to a community with a median income above the national level. The data illustrates that there is little downward social mobility for those who 
during adolescence were raised in environments of higher standing. Those variables that measure higher social status demonstrate that individuals with privilege move to communities with desirable median incomes.

The portrait of migration that emerges from the NLSY79 data depicts that those born to privilege live in higher median income communities. Only one-third of this population is downwardly mobile. Upward mobility for those from lower status adolescence communities is nearly even with approximately half moving to desirable communities and the other half moving to undesirable communities. Those with lower education levels tend to move to undesirable communities with $71 \%$ of the respondents who have less than a high school education living in undesirable communities in 2002. With lower levels of education, the mover population tends to cluster in undesirable communities supporting the theory that movers tend to move to homogeneous communities where individuals of similar status live.

Economic theories of migration hold that individuals migrate for economic reasons. Migrants when they move tend to minimizing risk and to maximize the opportunities associated with migration. If migration was based only on economics, moving from undesirable communities to desirable would be the predominate move. Communities that have a high income levels provide more as well as better services to their citizens. In such communities even the poor have a better quality of services than are provided to the wealthy in undesirable communities. Because of the quality of life in these desirable communities it would be expected that all movers would move to desirable communities.

The data from the NLSY79, however, explains that those who lived in undesirable counties at 14 years of age had a $50 \%$ rate of moving to counties with a desirable median 
income level by their middle age. Of the population that moved from desirable counties of origin, $67 \%$ were able to move to another desirable community in 2002 . The data illustrates that there is a tendency to move to desirable communities in 2002 for both those who lived at age 14 in both desirable and undesirable communities of origin. This finding supports economic theories of migration that state that migration takes place for potential economic benefits.

These findings also tend to suggest that the economic and social status of the community where the study participants lived during adolescence influences the type of community where they lived later in life. This conclusion must be tempered by the fact that "Family Poverty Level at 14" for those how lived in poverty is negatively correlated to being able to move to a desirable community. The data also confirm that education is positively correlated to moving to a desirable community, meaning that as an individual's income level increases their chances improve for living in a community above the poverty level.

Individual social economic variables in this study point to the premise that individual social-economic variables influence the location where a mover lives during middle age since the data shows that those from a family living above the poverty level, and those with higher educational achievement, have a higher chance of living in a desirable community than those from families below the poverty level, with low educational achievement. 


\section{WORKS CITED}

Adelman, Robert M., and Stewart E. Tolnay. 2003. "Occupational Status of Immigrants and African Americans at the Beginning and End of the Great Migration" Sociological Perspective 46(2):179-206.

Alexander, J. Trent. 2005. "They're Never Here More Than a Year: Return migration in the Southern Exodus, 1940-1970" Journal of Social History 38:653-671.

Allison, Paul D. 1984. Event History Analysis: Regression for Longitudinal Event Data Sage University Paper, Newbury Park, CA.

Baryla, Edward A., and Douglas Dotterweich. 2001. "Student Migration: Do Significant Factors Vary by Region?” Education and Economics 9(3):269-280.

Bielby, William T., and Denis D. Bielby. 1992. "I will Follow Him: Family Ties, Gender-Role Beliefs and Reluctance to Relocate for a Better Job" The American Journal of Sociology 97(5)1241-1267.

Blau, Peter M., and Otis Dudley Duncan 1967. The American Occupational Structure, Free Press

Borjas, George J., Stephen G Wronars and Stephen J. Trejo. 1990. "Self-Selection and Internal Migration in the United States" Discussion Paper, National Longitudinal Surveys, United States Department of Labor, Bureau of Labor Statistics, NLS 9214.

Braswell, Cara Mia, and Robert W. Gottesman. 2001. "Analysis of Factors Influencing Employment Migration of Recent Degree Recipients" Auburn University, Paper Presented at the $41^{\text {st }}$ Annual Forum of the Association for Institutional Research, Long Beach, CA, June 3-4, 2001.

Bureau of Economic Analysis. 1994. Local Area Personal Income 1969-92. Washington DC: United States Department of Commerce.

Bureau of Labor Statistics. 2006. NLSY79 User's Guide: A Guide to the 1979-2004 National Longitudinal Survey of Youth Data. Columbus Ohio, Prepared for the U.S. Department of Labor by Center for Human Resource Research, The Ohio State University, Columbus, Ohio. United States Department of Commerce.

Bureau of Labor Statistics. 2006. "National Longitudinal Surveys, All Cohorts, May 2006, CDrom U.S Department of Labor, United States Department of Commerce. Available: NLS User Services 614-442-7366.

Cadwallader, Martin. 1992. Migration and Residential Mobility: Macro and Micro Approaches, Madison, Wisconsin: University of Wisconsin Press. 
Chriswick, Berry R. 2000. “Are Immigrants Favorably Self-Selected? An Economic Analysis" Discussion Paper 131, University of Illinois at Chicago and Institute for the Study of Labor Boon, Germany.

Cotè, Guy L. 1997. "Socio-Economic Attainment, Regional Disparities, and Internal Migration” European Sociological Review 13(1):55-77.

Cushing, Brian. 2003. "State Minimum Wage Laws and the Migration of the Poor" Regional Research Paper 2003-3, West Virginia University, Morgantown WV.

DaVanzo, Julie. 1983. "Repeat Migration in the United States: Who Moves Back and Who Moves On?" The Review of Economics and Statistics 65(4):552-559.

Duncan, Cynthia M. 1992 Worlds Apart: Why Poverty Persists in Rural America, New Haven CT: Yale University Press.

Economic Research Service. 2003. "Measuring Rurality: What is Rural?" Washington, DC: United States Department of Agriculture. Retrieved 10/3/2006.

Economic Research Service. 2003. "Measuring Rurality: Urban Influence Codes" Washington, DC: United States Department of Agriculture. Retrieved 10/3/2006

Economic Research Service. 2004. "Measuring Rurality: Rural-Urban Continuum Codes" Washington, DC: United States Department of Agriculture. Retrieved 10/3/2006

Fulton, John A., and Glenn V. Fuguitt, Richard M. Gibson. 1997. "Recent Changes in Metropolitan-Nonmetropolitan Migration Streams" Rural Sociology 62(3):363384.

Frazis, Harley J., and James R. Speletzer. 2005. "Worker Training: What We've Learned from the NLSY79” Monthly Labor Review February pp. 48-58.

Frey, William H. 2004. "The New Great Migration: Black Americans' Return to the South 1965-2000” The Living Cities Series, The Brookings Institution May, 2004.

Frey, William H., and Kao-Lee Liaw. 2005. Interstate Migration of Hispanics, Asians and Blacks: Cultural Constraints and Middle Class Flight” Population Studies Center, Report 05-5, May 2005, Population Studies Center, University of Michigan Institute for Social Research. 
Goetz, Stephen J. "Migration and Local Labor Markets" The Web Book of Regional Science, Regional Research Institute, West Virginia University. Accessed at http://www.rri.wvu.edu/WebBook/Goetz/. October 3, 2005.

Greenwood, Michael J. 1975. "Simultaneity Bias in Migration Models: An Empirical Examination” Demography 12(3):521-544.

Greenwood Michael J. 1975. "Research on Internal Migration in the United States: A Survey" Journal of Economics 13(2):397-433.

Greenwood, Michael J. 1985. "Human Migration: Theory, Models and Empirical Studies" Journal of Regional Science 25(4):521-544.

Greenwood, Michael J., and Patrick J. Gormely. 1971. "A Comparison of the Determinants of White and Nonwhite Interstate Migration" Demography 8(1):141-155

Greenwood, Michael J., Gary L. Hunt, Dan S. Rickman, and George I. Treyz. 1991. "Migration, Regional Equilibrium and the Estimation of Compensating Differentials" The American Economic Review 81(5):1382-1390.

Gurak, Douglas T., and Mary M. Kritz. 2000. "The Interstate Migration of U.S. Immigrants: Individual and Contextual Determinates” Social Forces 73(3):10171039.

Haurin, Donald R., and Jean R Haurin. 1988. "Net Migration, Unemployment, and the Business Cycle” Journal of Regional Science 28(2):239-254.

Heuer, Ruth E. 2004. "Migration of Recent College Graduates" Ph.D. dissertation, Department of Sociology, North Carolina State University, Raleigh, NC.

Huang, Tzu-Ling, Peter F. Prazem, and Darin Wohlgemuth. 2002. "Rural Population Growth, 1950-1990: The Role of Human Capital, Industry Structure and Government Policy” American Journal Agricultural Economics August 2002:615-627.

Kodrzycki, Yolamda L. 2001. "Migration of Recent College Graduates: Evidence from the National Longitudinal Survey of Youth" New England Economic Review January/February.

Kramer, Judith R. 1970. The American Minority Community, Thomas Y. Crowell Company, New York, NY.

Lee, Everett S. 1966. “A Theory of Migration” Demography 3(1):47-57. 
Lee, Seong Woo, and Curtis C. Roseman. 1999. "Migration Determinates and Employment Consequences of White and Black Families 1985-1990" Economic Geography 75(2):109-133.

Lin, Nan. 2001. Social Capital A Theory of Social Structure and Action Cambridge University Press New York, NY.

Logan, John R. 1978. "Growth, Politics and the Stratification of Places" The Journal of Sociology 84(2):404-416.

Logan, John R., and Richard D. Alba, Tom Mcnulty, Brian Fisher. 1996. "Making a Place in the Metropolis: Locational Attainment in Cities and Suburbs" Demography 33(4):443-455.

Logan, John R., and Harvey L. Molotch. 1987. Urban Fortunes: The Political Economy of Place. Berkeley: University of California Press.

Massey, Douglas S. 1990. "Social Structure, Household Strategies and the Cumulative Causation of Migration" Population Index 56(1):3-36.

Mangalam, J. J. and Harry K Schwarzweller. 1968. General Theory in the Migration: Current Needs and Difficulties" International Migration Review 3(1):3-18.

Massey, Douglas S. 1996. "The Age of Extremes: Concentrated Affluence and Poverty in the Twenty-First Century" Demography 33(4):395-412.

Massey, Douglas S., and Nancy A Denton. 1985. "Spatial Assimilation as a Socioeconomic Outcome" American Sociological Review 50(1):94-106.

Mincer, Jacob. 1978. "Family Migration Decisions" The Journal of Political Economy 86(5):749-773.

Obermiller, Phillip J., and Steven R Howe. 2000. "Moving Mountains: Appalachian Migration Patterns 1995-2000" Journal of Appalachian Studies 10(3):359-371.

Obermiller, Phillip J., and Steven R. Howe. 2001. "New Paths and Patterns of Appalachian Migration 1975-1990" Journal of Appalachian Studies 7(2):331-349.

Obermiller, Phillip J., and Steven R. Howe. 2004. “Appalachian Migration Pattern 19751980 and 1985-1990" Appalachian Regional Commission, Washington DC.

Obermiller, Phillip J., and Michael E. Maloney. 2002. Appalachian Social Context Past and Present Kendall/Hunt Publishing Company.

Parsons, Talcott. 1951. The Social System, New York, McGraw-Hill. 
Ravenstein, E.G. 1885. "Laws of Migration.” Journal of the Statistical Society XLVII, Part II:167-235.

Ravenstein, E.G 1989. "The Laws of Migration" Journal of the Royal Statistical Society 52(2):241-305.

Schwarzweller, Harry K., James S. Brown and J.J. Mangalam. 1971. Mountain Families in Transition; A Case Study of Appalachian Migration, University Park, PA, The Pennsylvania State University Press.

Seyfrit, Carol L. 1986. "Migration Intention of Rural Youth: Testing an Assumed Benefit of Rapid Growth" Rural Sociology 51(2):1040-1084.

Sjaastad, L.A, 1962. "The Costs and Returns of Human Migration" Journal of Political Economy 70:80-83.

South, Scott J. and Kyle D Crowder. 1997. "Escaping Distressed Neighborhoods: Individual, Community, and Metropolitan Influences" American Journal of Sociology 102:1040-1084.

Spitze, Glenna. 1984. "Black Family Migration and Wives' Employment” Journal of Marriage and the Family 46(4):781-790.

Tickamyer, Ann R. and Cynthia M. Duncan. 1990. "Poverty and Opportunity Structure in Rural America" Annual Review of Sociology 16:67-87.

Todaro, M. P. 1969. “A Model of Labor Migration and Urban Unemployment in Less Developed Countries" American Economic Review 59(1):138-148.

Tönnies, Ferdinand. 2002. Community and Society Dover Mineola, New York.

Tolnay, Stewart E., Robert M. Adelman, Kyle D. Crowder. 2002. "Race, Regional Origin and Residence in Northern Cities at the Beginning of the Great Migration" American Sociological Review 67(3):456-475.

U.S Census Bureau. 1979. 1977 County and City Data Book United States Census Bureau, United States Department of Commerce Washington DC.

U.S Census Bureau. 1996. 1994 County and City Data Book United States Census Bureau, United States Department of Commerce Washington DC.

U.S Census Bureau. 2004. "Geographical Mobility: 2002-2003 Census 2003” Population Characteristics P20-549 United States Census Bureau, United States Department of Commerce Washington DC. 
U.S. Census Bureau. 2005. "Areas with Concentrated Poverty: 199" Census 2000 Special: Reports Censr-16 United States Census Bureau, United States Department of Commerce Washington DC.

U.S. Census Bureau. 2005. "Income, Earnings and Poverty from the 2004 American Community Survey" Census 2000 Special; Reports Censr-16 United States Census Bureau, United States Department of Commerce Washington DC.

Weber, Max, W.G. Runciman, E. Matthews 1978. Max Weber: Selections in Translation Cambridge University Press, Cambridge UK.

Wenk, Dee Ann, Constance Hardesty. 1993. "The Effects of Rural-to-Urban Migration on the Poverty Status of Youth in the 1980's" Rural Sociology 58(1):76-92.

Wilson, William Julius. 1996. When Work Disappears. The World of the New Urban Poor, Vintage.

Wright, Richard, Mark Ellis, and Virginia Parks. 2005. "Re-placing Whiteness in Spatial Assimilation Research" City \& Community 4(2):111-135.

Yaukey, David, Douglas L. Anderton, Jennifer Hickes Lundquist. 2007. Demography, The Study of Human Population. Long Grove, IL, Westland Press.

Zimmerman, Carle C., Merle E. Frampton, 1935. Family and Society, New York, D. Van Nostrand Company. 